\title{
"Hell Witches in Toronto" Notes on Lesbian Visibility in Early-Twentieth-Century Canada
}

\section{Steven Maynard}

One of the most persistent and pressing problems in the research and writing of lesbian history in Canada, particularly for periods prior to World War Two, is the presumed paucity of primary historical sources. What little we do know about early-twentieth-century lesbian history in Canada comes to us primarily through the private letters, diaries, and memoirs of white, middle-class women. Some very significant discoveries have been made, including the letters and autobiography of poet Elsa Gidlow in Montreal, the journals of Constance Grey Swartz of British Columbia, and the correspondence between Doctor Frieda Fraser and Edith Bickerton Williams in Toronto. These rich sources reveal the inner thoughts and feelings of women attracted to other women, and they give us glimpses into the early-twentieth-century bohemian milieux and professional ranks that could nourish same-sex relations among well-educated and well-travelled white women. ${ }^{1}$ Still, those interested in recovering the lesbian past often lament the lack of sources like the legal records relied upon by gay historians to reconstruct the history of gay male identities and subcultures. Karen Duder, one of the few to explore the terrain of lesbian history in Canada prior to World War Two, explains that "the dearth of information is hardly surprising given the limited availability of lesbians' personal records and the equally limited purview of the state in the area of lesbian sexuality." "2 But personal papers and state-generated documents are only two possible sources. In the following research report, I want to draw attention to a small but significant cache of articles from the early tabloid press that not only signals the potential of print media in lesbian historical research but also calls into question some of our assumptions about lesbian history in pre-World War Two Canada.

That the early tabloid press might prove to be a useful source for earlytwentieth-century lesbian history makes a good deal of sense when we consider how invaluable tabloids (and, of course, oral histories) have been in recuperating the postwar gay/lesbian past in Canada. ${ }^{3}$ The tabloids reflect the more general significance of print culture, from physique magazines to lesbian pulp novels and the lesbian-themed stories of Chatelaine, in the making of postwar gay/lesbian subcultures. ${ }^{4}$ But if pulp novels, like the rough working-class 
world of lesbian bars, were associated primarily with the postwar growth of urban lesbian communities, and therefore unlikely sources for pre-war lesbian history, the same does not hold true for tabloids. In my own research on the gay history of early-twentieth-century Toronto, tabloids have proven immensely useful, and it was in the course of that research I stumbled upon "hell witches" and "man-women" in Toronto.

On 11 October 1928 the Toronto tabloid, Hush, ran a story about a "Secret Novel Banned in England." The book, of course, was Radclyffe Hall's lesbian novel, The Well of Loneliness. "The Wells of Loneliness," as Hush initially referred to it, was a story in which "Miss Hall seeks not only to explain her pervert 'heroine,' but also to justify her." This was the first of four articles Hush devoted to the infamous obscenity trial, and they appeared in the tabloid between October 1928 and January 1929. In the spring of 1929, Hush published five more articles. These were not about The Well, but part of a "special series of articles" dealing with lesbianism, or, as Hush's writer put it, "one of the vilest of the hidden vices of modern society." In addition to these nine articles, I also located two more lesbian-themed pieces, one from October 1929 and one from a later period, March $1940 .{ }^{6}$ I was excited to discover lesbian references in the pages of Hush, though not altogether surprised. Over ten years ago, I happened upon another article on the banning of The Well, this one penned by S. H. Hooke and published in April 1929 in the Canadian Forum, a highbrow venue very different from $H u s h .^{7}$ Taken together, the Canadian Forum and Hush articles attest to what lesbian historians have long maintained: The Well trial represented a crucial moment in the public identification, elaboration and circulation of a modern lesbian identity and culture.

In her provocative book, Fashioning Sapphism, Laura Doan concurs that the highly publicized obscenity trial of Hall's novel was "the crystallizing moment in the construction of a visible modern English lesbian subculture," even as Doan's original research and rigorous historicization tear down the many myths that have grown up around the Hall affair. Doan proposes "an alternative genealogy of modern English lesbian culture" by locating Hall "within the 'constructed narrative' of English modernity through the multiple sites of law, sexology, fashion, and literary and visual representation." Doan's exploration of what she terms "Sapphic modernity" constitutes "a new direction in lesbian historiography by its insistence on a particularized national context and temporality."8 Notwithstanding Doan's important insistence on national context, the material under consideration here suggests the sometimes diffuse, transnational nature of culture: the discursive explosion of lesbianism occasioned by The Well trial had ripple effects felt in places as far away as Toronto. Before turning to Hush's treatment of lesbianism, it will be useful to provide a bit of background on the tabloids.

Our historical knowledge of the early tabloid press in Canada remains 
incomplete. Much of what we do know comes from an important, pioneering study by historian Susan Houston. Muckraking tabloids, Houston explains, first emerged in the opening decades of the twentieth century. Jack Canuck, for example, one of the better-known early tabloids, began publishing in 1911. But it was during the interwar period that the tabloid industry took off. Established in 1927 by owner/editor Strathearn Boyd Thomson, who Houston characterizes as a "socially well-connected but disaffected horse-breeder cum promoter," Hush was only one of several papers that made Toronto the tabloid capital of Canada. Published weekly, tabloids were cheap -5 cents a copy. They enjoyed national exposure, and their circulation often outstripped that of established elite periodicals, such as Saturday Night and Canadian Forum. Through its distributor, Hush reached big urban centres and small farming communities; by 1931, Hush put out an eastern (Ontario, Quebec, and the Maritimes) and a western edition. Tabloids like Hush cultivated a wide audience by combining its Toronto coverage with columns devoted to happenings in other places, such as Ottawa, Hamilton, Calgary, and, on a few occasions, even London, England. Hush's series on lesbianism was written by a nameless "special commissioner" who appears to have been based in London. Indeed, sizable chunks of some of Hush's lesbian articles read as though they were written for British publications with Toronto material tacked on, either within the articles or as a preface to them, by the special correspondent and/or Hush's editor. This would be in keeping with Houston's finding that reporters for other publications often "moonlighted as the anonymous out-of-town stringer for a Toronto tabloid." In terms of politics, tabloids were guided by a generalized populism - they purported to speak Truth and Justice for the People and against Big Interests - and their journalistic practice relied heavily on sensationalism, including of course substantial offerings of sex and sleaze. And who read the tabloids? It's a difficult question to get at historically, but Houston suggests that the audience included "more than a handful of self-styled civic moralists who followed the tabloids in order to monitor the tastes of ordinary working people," along with "those with a prurient interest in matters not generally talked about in public." But most readers, Houston believes, read the tabloids for entertainment: "The spice of scandal and the editorial antics of these papers attracted an eclectic readership which crossed class and gender boundaries despite strong whiffs of the barber shop and pool room." What then can we say in a tentative way about the work of Hush in relation to lesbianism in the late-1920s?

Hush gave a name to what contemporaries sometimes referred to as the "nameless vice between women." Indeed, it would appear that a rather elaborate language of lesbianism already existed and/or was put into circulation by the tabloid. In its very first report, Hush declared that "it is our opinion that Miss Hall did not propose to publish anything that sophisticated people do not know all about." 10 But who were these sophisticated readers? "Knowledge of 
lesbianism," Doan writes, was "one significant marker or index of class separating the sophisticated from 'the masses' ... In reviewing The Well of Loneliness the more elite journals, which were pitched to a well-educated and informed, albeit small, readership, used the same terminology as some of the sexologists." For readers of publications like the Canadian Forum, who no doubt fancied themselves among the sophisticated people in the know, lesbianism was indeed depicted in sexological terms. Hooke, conversant in "abnormal sex-psychology," described The Well as "a study of sex-inversion," and referred throughout his article to lesbians as "inverts." In keeping with a magazine of liberal, middle-class opinion, Hooke came out against censorship and took up Hall's plea for tolerance. "There is not an objectionable line in the book, nothing of lubricity, or suggestiveness," wrote Hooke. What got people's knickers in a knot, and needlessly so according to Hooke, was that the novel presented "sexual inversion as a social fact, of depicting an invert not as an object of repulsion and horror, but as demanding pity for a fate imposed by unthinking nature, and as seeking an outlet for emotions which, unnatural to the normal individual, are natural to the invert."11

Hush did not regard knowledge of lesbianism as something that should be restricted to readers of elite periodicals: "it would be well for those who do not know, to have the blinds pulled away from their eyes - there is nothing to be gained by ignorance." In marked contrast to the Canadian Forum, Hush drew upon an evocative, popular language of lesbianism, including "votaries at the shrine of Lesbia," "daughters of Lesbia," "hell witches," and "perverts." This is congruent with Doan's findings that "there was also an extensive range of unscientific and far from neutral phrases in the coverage of the controversy in the popular press." 12 There are also indications that medical understandings were filtering down from sexological writings and/or elite journals to the popular press. One Hush article pointed out that "Doctors are frequently uttering grave warnings as to the dangers of psycho-analysis in this connexion ... The all powerful influence of the mind over the body, burned inwards and out of its natural course, produces inverted growth." ${ }^{\prime 13}$ What exactly was referred to in this often euphemistic mix of moral and medical language? Doan reports that in all of the British sources she looked at, just one - a highbrow journal referred explicitly to "Lesbian," and "homo-sexual" and "homosexuality" appeared only in elite periodicals and medical journals. Hush, by contrast, didn't tiptoe around. Not bound like more established papers by the conventions of linguistic decorum, and partaking instead in the tabloid tradition of speaking frankly, Hush made clear right from the get-go what was at issue: "the various phases of Lesbianism." The boldfaced title of the tabloid's second article drove the point home: "Ethics of Lesbianism Banned" (Figure 1). Even in this small sample of tabloid reports, the term "lesbianism" appeared at least five times, and if doubt about the meaning of any of its terms persisted, Hush spelled it 
out: lesbianism referred to a "certain class of perverted women who fall in love with other women." 14

In addition to circulating the language of lesbianism, the tabloid also localized it. In the first several reports, lesbians were to be found elsewhere: "Hush has seen many of these creatures in the society of London and New York." On two different occasions, Hush reported on a "play called The Captive which ran

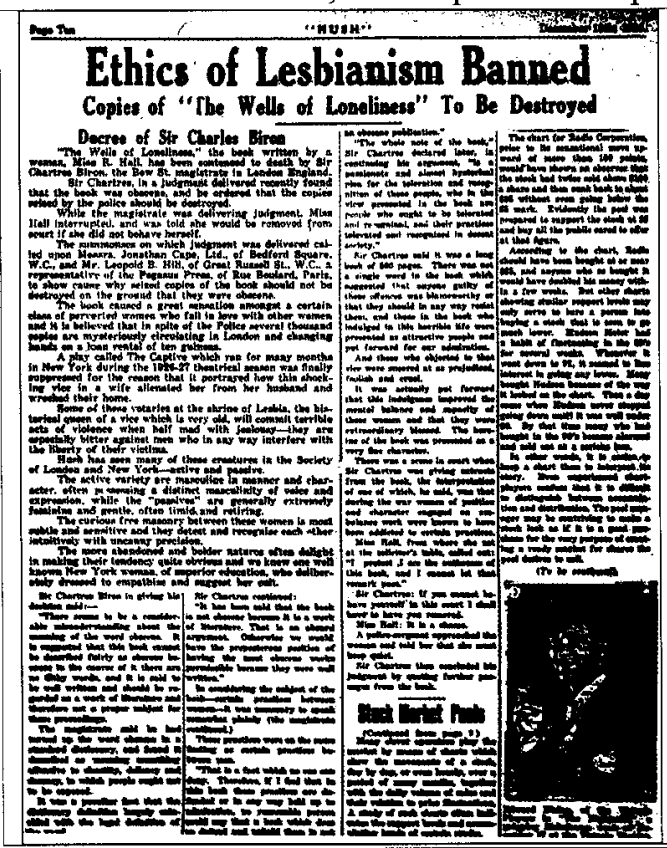

Figure 1

for many months in New York during the 1926-27 theatrical season [and] was finally suppressed for the reason that it portrayed how this shocking vice in a wife alienated her from her husband and wrecked their home." 15 Stories on the uproar caused by sensational cases such as The Captive and The Well are significant in themselves in that they suggest at least some in Toronto were cognizant of lesbian culture in other places. But what about in Toronto? One report pondered what to do "should it be decided that Lesbianism was prevalent in Toronto." Such ambivalent statements coexisted alongside seemingly

more certain awareness. In "Oh! Ye Daughters of Lesbia," the reporter confidently claimed that "these evils undoubtedly exist in Toronto," while another noted that "there are several couples of women in Toronto, living as 'man' and wife." 16 Uncertainty about the extent of lesbianism in Toronto, and the fact the tabloid could identify only several lesbian couples in the city, suggest we are looking at, if not an early moment in the emergence of lesbian identity, then at least an early moment in the public apprehension of lesbianism. Again, this is in line with Doan's argument that the trial of The Well did not represent the climax of a more than decade-long attack on the "lesbian menace," an interpretation that obviously presupposes the existence of a lesbian identity and subculture, but that the trial was a key moment in the fashioning of that subculture by bringing together broader cultural currents - the varied "origins" in Doan's subtitle - and fixing them ever after to the stylish figure of Radclyffe Hall and her novel of female sexual inversion. 
Hush also offered Torontonians an image of lesbians. Hush divided lesbians into "active and passive," explaining that "the active variety are masculine in manner and character, often possessing a distinct masculinity of voice and expression, while the 'passives' are generally extremely feminine and gentle, often timid and retiring." But Hush devoted most of its attention to what Esther Newton has called the "mythic mannish lesbian." "A Man-Woman Wrecks Her Home" explained that you could tell a "man-woman" by "her closely-cropped hair, her masculine mode of attire, her at times unfeminine coarseness of speech, her habit of whistling, her swagger." 17 In addition to these general portraits of female masculinity, Hush introduced readers to one particular Toronto lesbian, "a woman of most unusual and pronounced masculine character": "Mrs. X, as we will call her, is described to us as weighing over two hundred pounds, with jet black hair, cut like a college boy, rather on the long side and parted down the left side. She is said to be about thirty seven years old and quite handsome." Mrs. X was the central character in "Hell Witches in Toronto," the Hush story about a "Rosedale studio, where flagellations had undoubtedly been indulged in" (Figure 2). At this Rosedale studio, one found:

'parties' where as many as eight of these women were present; after they had become thoroughly intoxicated and stimulated by smoking drug soaked cigarettes, one of them suggested that they telephone for Mrs. X. This delightful creature in due course arrived, armed with a birch rod in a heavy silken sheath. She was first primed with liquor and then proceeded to thrash the eight Lesbians on a certain part of their anatomy, which they vied with each other in exposing to facilitate the onslaughts of the 'Master.' Some of them shrieked with pain, others laughed and two of them wept. Mrs. X seemed to take delight in further persecuting those who appeared in the worst pain, which he [Hush's informant] explained was consistent with the 'disease.' After the punishment was over, Mrs. X made pronounced advances, in a masculine manner, to one of the 'sisters' and finally asked her to come home with her - they departed. ${ }^{18}$

The following month, in "Shameless Women's Terrible Toll," readers were treated to another detailed description of a party at which "one by one the women discard the garments with which they have been so thinly clothed, and abandon themselves to the wildest ecstasies ... Before many moments have passed several couples are locked in each other's arms ... Then there comes another device to pander to the intensity of their animal passions. I refer to the 
use of the birch, which is a regular feature of these bestial orgies." The writer claimed that such orgies "are taking place by the dozen, nightly - and in the afternoons as well - in London, England and undoubtedly on lesser occasions in Toronto." The truth of these tales is highly doubtful; the plot of the Rosedale

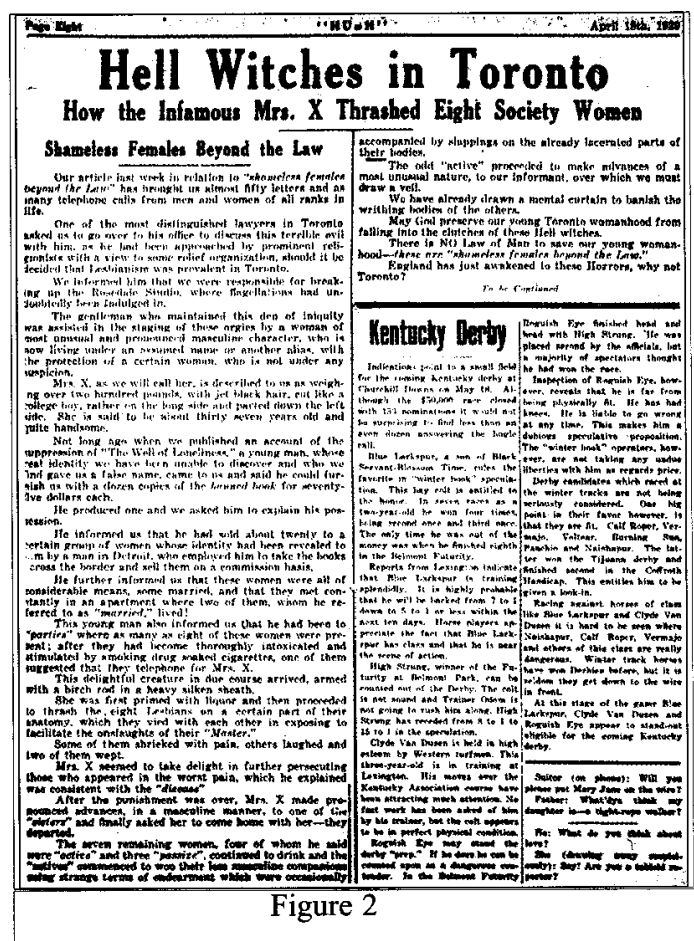
story resembles far too closely the narratives of lesbian flagellation in London that preceded and followed it in the paper. Martha Vicinus has touched on this interweaving of lesbian narratives with "pre-existing pornographic plots with little consideration for historical facts." Vicinus argues that "we should not dismiss this material, for such culturally influential male fantasies, derived from both pornography and high art, had a lasting impact upon the public (and occasionally, the private) image of the lesbian."19 In "Another Woman 'Weds' a Woman," we discover yet another narrative the cross-dressing female husband - which lesbian his-

torians have traced from the late-eighteenth century well into the twentieth century. Any historian trying to use these articles to piece together a lesbian history will have to come to interpretive terms with the tabloid's oscillation between hard news and soft porn, exploring the recurrent narratives employed by the paper to represent lesbianism. As Hush described one of its own reports on a "masculine woman," it "reads like a masterpiece of French fiction."20

Tales of lesbian flagellation fit easily within Hush's sensationalist strategy to titillate in order to sell papers. But stories of a lesbian $\mathrm{s} / \mathrm{m}$ studio in Rosedale served other purposes as well. The location of "this den of iniquity" in Rosedale and the characterization of lesbians as "society women" reflected the tabloid's penchant for pointing out all manner of perversity among Toronto's elite. As Houston discovered, Hush delighted in scandal, "with reams devoted to Rosedale gossip." ${ }^{11}$ In my research on gay men, I found they were also often represented as the privileged progeny of Rosedale society. This points to the political utility of perversity for the tabloids. By depicting lesbianism and male 
homosexuality as symptoms of upper-class decadence, while generally ignoring same-sex relations among the 'lower orders,' Hush harnessed homosexuality and cultural prejudice against it to further its critique of a corrupt and privileged Toronto elite. Locating homosexuality in Rosedale also cast lesbians and gay men as white, although the tabloid failed to mark such whiteness. This reluctance to register race did not extend to other residents of the city. The early tabloids frequently denigrated Toronto's racial and immigrant minorities by assigning to them a "depraved" sexuality. Jack Canuck, for instance, depicted Chinese men as simultaneously effeminate but still sexually dangerous, always waiting to lure white working women into their restaurants and opium dens. ${ }^{22}$ By displacing "deviant" sexualities onto the white upper class and the nonwhite, immigrant working class, the tabloids effectively defined their populism and their imagined constituency in terms of white, heteronormative working men and women.

Not all of Hush's observations, however, were too fabulous to have been fact. Consider this Hush informant's description of Toronto lesbians: "these women were all of considerable means, some married, and ... they met constantly in an apartment where two of them, whom he referred to as 'married,' lived!" On the one hand, the informant's comments replay Hush's belief that lesbianism was confined to Rosedale ladies. On the other hand, the idea that lesbian networks in late-1920s Toronto were, in part, made up of white, middle-class women who could afford to live together, entertaining other women in the privacy of their own apartments, is rather more believable than (though perhaps not as satisfying as) tabloid tales of "How the Infamous Mrs. X Thrashed Eight Society Women." Given Hush's particular class slant on lesbianism, it follows that the tabloid reveals less about same-sex relations among non-elite women. Some of the stories of "man-women," however, which often involved women cross-dressing partly in order to work at men's jobs, might give us a different perspective. Frances/Frank Stevenson, whose story I'll return to in a moment, told the court that "she acted as a man so she "could get a job more easily. The pay is better too,' she added, 'and when travelling on the road it is so much safer." The tabloid's perceptive comments about the dynamics of lesbian recognition also ring true: "The curious free masonry between these women is most subtle and sensitive and they detect and recognize each other intuitively with uncanny precision. The more abandoned and bolder natures often delight in making their tendency quite obvious." Hush's frequent flights of fancy stand in marked contrast to its otherwise grounded, historical understanding of lesbianism as the peculiar outgrowth of "these unconventional times": "In the past, such types have been so rare or so successfully concealed that most of the world has remained in ignorance ... Today, these creatures have a cult of their own, and a literature which they seek to flaunt in the open market." The tabloid related the increased openness of lesbians to "the 
development of the modern girl," including "the devotion to sport and the physical culture," "work done by women in factories and offices," and the "'Feminist Movement' [which] has among its supporters many degenerates of both sexes." These forces were responsible for "developing masculine propensities" among modern women, precipitating a dangerous shift in the balance of power between the sexes - "Sexually, woman is taking the initiative away from man and is assuming control of his destiny" - and producing "a most loathsome type of hybrid creature ... the man-woman."23

Whether fact or fiction, what can be said about the possible cultural effects of Hush's foray into the subject of lesbianism? The paper claimed that its coverage "caused a mild sensation," with concerned citizens contacting the paper to propose solutions to the emerging problem of lesbianism in Toronto. "One prominent church supporter writes: These social evils should be exposed exposure is the best deterrent to these warped sinful creatures." In "Hell Witches in Toronto," Hush explained that "Our article last week ... has brought us almost fifty letters and as many telephone calls from men and women of all ranks in life. One of the most distinguished lawyers in Toronto asked us to go over to his office to discuss this terrible evil with him, as he had been approached by prominent religionists with a view to some relief organization." The article ended on an ominous note: "May God preserve our young Toronto womanhood from falling into the clutches of these Hell witches ... England has just awakened to these Horrors, why not Toronto?" Within a month, fifty letters had multiplied into "the hundreds of letters which have poured into our office the past few weeks in connection with this special series of articles. ${ }^{24}$ It is difficult not to detect in these escalating reports an effort by the tabloid to provoke a response against the lesbian threat, a threat Hush of course played a major role in fabricating. What, if any, local political happenings or people prompted Hush's editor, Strathearn Boyd Thomson, to devote so much space to the issue of lesbianism is an intriguing question that will require further research. As Houston explains, tabloids were often driven by a "moralizing mission." The editors of several tabloids, including Thomson, pointed to Henry Labouchere's crusading London tabloid, Truth, as a source of inspiration, something that may take on added meaning when we recall that the 1885 British amendment criminalizing gross indecency between men bears Labouchere's name. Recall, too, the unsuccessful British attempt in 1921 to extend the Labouchere Amendment to cover acts of gross indecency between women. What would the goal of Hush's lesbian campaign have been? Criminalizing sexual relations between women is one possibility. The special correspondent pointed to a "peculiar legal anomaly": "While male persons guilty of unnatural acts are diligently prosecuted and heavily punished ... like conduct between females, strange as it may seem, appears to come outside the cognizance of the Law - at any rate, I have never come across the record of 
even a prosecution." Much to the writer's chagrin (and, for different reasons, to the great dismay of latter-day lesbian historians), lesbians were "shameless females beyond the law." Hush took up this designation, using it on several occasions to underscore the absence of any law against sexual activity between women: "There is NO law of Man to save our young womanhood - these are 'shameless females beyond the Law." 25 But if a move to criminalize sexual relations between women was on the minds of some at Hush, it never got off the ground; the criminalization of lesbianism, via the extension of the law against gross indecency to females, would not happen in Canada until 1953.

Hush warned against hell witches in Toronto, but such negative messages may not have been the only possible reading or use of the tabloid. Following its report on the successful prosecution of The Well, Hush noted that "several very prominent society women have rung us up and asked if we had a copy of 'The Wells of Loneliness' to lend them. We were sorry to inform them that our copy had not arrived from England yet as the book had been banned ... We may never receive this much talked of work ... Hush is afraid that the Flairs and Lesbias of Toronto will have to shrivel in disappointment." It is of course impossible to determine the extent to which The Well was available in Toronto at this time. After its ban in England, the novel was published in the United States after successfully overturning an obscenity conviction there. We do know that Hooke had a review copy - "Covici-Friede, New York; $\$ 5$ " - before April of 1929. Other copies undoubtedly crossed the border into Canada. "Not long ago when we published an account of the suppression of 'The Well of Loneliness," Hush claimed, "a young man, whose real identity we have been unable to discover and who we find gave us a false name, came to us and said he could furnish us with a dozen copies of the banned book ... He produced one and we asked him to explain his possession. He informed us that he had sold about twenty to a certain group of women whose identity had been revealed to him by a man in Detroit, who employed him to take the books across the border and sell them on a commission basis." The larger point here is that Hush may have peddled negative messages about lesbianism, but it also advertised, maybe even stimulated a demand for, Hall's novel and an emerging lesbian culture. Such unintended consequences were not lost on Hooke: "But by the irony of life, society's blind reaction in the censorship to certain facts of life defeats itself. As a result of the ban upon The Well of Loneliness, thousands of people have read the book and become aware of the facts of inversion who would ordinarily never have seen the book, nor become cognizant of the facts which it deals with."26

The modest number of tabloid articles presented here prevents us from coming to any firm conclusions. They are suggestive enough, however, to caution against turning current claims about early-twentieth-century lesbian history in Canada into conclusions before the necessary empirical research has been 
done. For instance, Duder suggests that the "Canadian public had few sources of information about lesbianism before the mid-twentieth century," and what did exist was "primarily available to medical professionals." Referring more specifically to the Canadian Forum article on the trial of The Well, Duder further suggests that "Such information was most likely available to only a small proportion of the Canadian public." But the extensive coverage of the trial, along with follow-up forays into the lesbian world, in a popular tabloid like Hush, whose wide circulation surpassed that of elite periodicals, and whose readership reached well beyond medical professionals, suggest that knowledge of lesbianism may have been available to a broader spectrum of the public than we have previously imagined. Duder also states that "women had fewer opportunities to form the same kinds of sexual subcultures as did men," and that "before the Second World War, lesbians in particular remained virtually invisible in Canadian society." 27 In regard to the differences between men and women, the sources themselves are revealing: The 'private' nature of lesbian source materials in contrast to the 'public' court documents of male homosexual activity speak volumes about gender differences and inequalities in the often diverging histories of lesbians and gay men, including men's greater access to commercial and public sexual space. That said, we should be careful not to overdraw the distinction; the 'private' character of many lesbian sources does not necessarily translate into lesbian invisibility in public. Lesbians in 1920s Toronto may not have had the extensive, public and, by times, remarkably visible sexual subculture enjoyed by men who had sex with men. But public visibility can take many different forms. I would argue that the presence of lesbianism in the pages of periodicals and newspapers, from the lofty heights of Canadian Forum to the muckraking depths of Hush, constitute the press as one significant site of public lesbian visibility.

Such a view entails an understanding of the tabloids as a particular form of public space. Given Doan's heavy reliance on and careful readings of newspapers and other print sources, it is rather surprising that print media does not rank on Doan's list of, and hence is not analyzed as, one of the crucial sites in the making of Sapphic modernity. For help in conceptualizing the press as public space within lesbian history, we can turn to Lisa Duggan. In Sapphic Slashers, Duggan offers a sustained analysis of the mass circulation press as an "interactive public sphere" that produced and circulated a range of lesbian representations. Taking as her starting point the press reports of the $1892 \mathrm{Memphis}$ murder of Freda Ward by her lover Alice Mitchell, Duggan details the construction of the "lesbian love murder narrative," juxtaposing it with lynching narratives, to reveal the unsettling if familiar place of sex, race and violence in the making of US modernity. ${ }^{28}$ Similarly, we might view the tabloids as a later wave of this "new journalism," one consisting of mass-circulated, 5-cent scandal sheets that produced a visible public sphere for the sensational presentation 
of sexuality, including the spectacle of man-women and pansy boys.

If and how women who desired other women used the press as a site of self-fashioning, as a way to name their desires, remains an elusive question. Duder speculates that Constance Swartz, a voracious reader, including of the Canadian Forum, was likely "familiar with the controversy surrounding Radclyffe Hall's 1928 novel The Well of Loneliness." 29 What about Frieda Fraser and Edith Williams? Did they ever pick up a Toronto tabloid, or, given their gender and class position, was that simply too far beneath them? And what about the women who supposedly contacted Hush to inquire where they might be able to find a copy of The Well?

The extent to which tabloids and other papers might have functioned as a public space of lesbian visibility and/or identity formation will only be determined through primary historical research. Using the obscenity trial of The Well as a point of departure, we need an extensive search of Canadian print media, from middle-class periodicals to the tabloid press, to track how lesbianism was taken up in other magazines and newspapers. Hush was likely not the only paper in the country to cover the trial, and maybe not the only paper to use it as a springboard for investigations into lesbianism at the local level. The tabloids themselves suggest other research paths. In March 1940, for example, we learn that "Hamilton society rocked last week in startled amazement" when it was discovered that eighteen-year-old Frances, aka Frank, Stevenson "wielded a power and a fascination to young members of her own sex, while masquerading as a male." Frances's story, which included "going on petting parties for months with girls who never once suspected that their handsome boy friend could lay principle claim in fact to belonging to their own sex," came to light after being picked up on a vagrancy charge. ${ }^{30}$ We need an extensive search of the still mainly unprocessed lower criminal court records to locate those instances in which broad charges, such as vagrancy, and, after 1953, gross indecency were used against lesbians. Searching the tabloid press for stories of masculine women like Frances/Frank, and using the dates of these reports to pinpoint court records, if they still exist, is one potential research strategy. In any event, we must begin the painstaking, labour-intensive newspaper and archival research necessary to set (especially pre-World War Two) lesbian history in Canada on a firmer empirical foundation. The "Hell Witches of Toronto" suggest that such a project could prove both fruitful and fascinating.

Not long after The Well controversy erupted in the tabloid, Hush asserted that "Lesbianism has existed since the world began but it must not be lauded and written about, however choice and seductive the language." But Hush failed to follow its own advice, furnishing readers with its own seductive language and lurid tales of lesbianism. "Immoral traffic between men and women is, to some extent, understandable - if not, according to our social convention, 
forgivable," Hush explained. "But unnatural traffic between men and men is, in the minds of all right-thinking persons, to the last degree terrible, while traffic between women and women is an almost unspeakable and unimaginable horror and degradation." 31 The "almost" is significant, for Hush, from October 1928 to October 1929 and beyond, did its part to render lesbianism in Toronto speakable, imaginable, and visible.

My thanks to the journal's editors and reviewer for their very helpful comments. I'd also like to acknowledge Janice McLean for her abiding interest and intelligent questions.

Notes

${ }^{1}$ Elsa Gidlow, Elsa: I Come With My Songs (San Francisco: Booklegger Press, 1986); on Swartz, see Karen Duder, "Public Acts and Private Languages: Bisexuality and the Multiple Discourses of Constance Grey Swartz," BC Studies 136 (Winter 2002/03): 324; on Fraser and Williams, see Karen Duder, "That Repulsive Abnormal Creature I Heard of in That Book': Lesbians and Families in Ontario, 1920-1965," in Ontario Since Confederation: A Reader, ed. Edgar-Andre Montigny and Lori Chambers (Toronto: University of Toronto Press, 2000), 260-83.

2 Duder, "That Repulsive Abnormal Creature," 262. Martha Vicinus has offered the most sustained and searching reflections on the dilemmas of evidence for modern lesbian history. See, for example, Vicinus, "Lesbian History: All Theory and No Facts or All Facts and No Theory?," Radical History Review 60 (1994): 57-75; Vicinus, "They Wonder to Which Sex I Belong': The Historical Roots of the Modern Lesbian Identity," in The Lesbian and Gay Studies Reader, ed. Henry Abelove, Michele Aina Barale, and David Halperin (New York: Routledge, 1993), 432-52.

${ }^{3}$ See, for example, Eric Setliff, "Sex Fiends or Swish Kids?: Gay Men in Hush Free Press, 1946-1956," in Gendered Pasts: Historical Essays in Femininity and Masculinity in Canada, ed. Kathryn McPherson, Cecilia Morgan and Nancy M. Forestell (Toronto: Oxford University Press, 1999), 158-78; Jim Egan (compiled and edited by Donald W. McLeod), Challenging the Conspiracy of Silence: My Life as a Canadian Gay Activist (Toronto: Canadian Lesbian and Gay Archives and Homewood Books, 1998); Ross Higgins and Line Chamberland, "Mixed Messages: Gays and Lesbians in Montreal Yellow Papers in the 1950s," in The Challenge of Modernity: a Reader on PostConfederation Canada, ed. Ian McKay (Toronto: McGraw-Hill Ryerson, 1992), 422-38. The tabloids discussed by the authors cited here were mainstream publications. Another key aspect of this history was the emergence of the first gay tabloids. See Donald W. McLeod, A Brief History of 'Gay': Canada's First Gay Tabloid, 1964-1966 (Toronto: Homewood Books, 2003).

4 See, for example, Mary Louise Adams, "Lesbianism as Obscenity or Women's Barracks as a Threat to Girls," in The Trouble With Normal: Postwar Youth and the Making of Heterosexuality (Toronto: University of Toronto Press, 1997), 158-165; 
Valerie Korinek, “'Don't Let Your Girlfriends Ruin Your Marriage': Lesbian Imagery in Chatelaine Magazine, 1950-1969," Journal of Canadian Studies 33 (Fall 1998): 83109. One work on lesbian history during the $1950 \mathrm{~s}-60 \mathrm{~s}$ that attests to the significance of both pulp novels and tabloids is Forbidden Love, NFB, documentary, dir. Aerlyn Weissman and Lynn Fernie, 1992. See also Steven Maynard, "Pulp Novels and Other Pleasures: Lesbian History in the 1950s and "60s - an Interview with Filmmakers Lynn Fernie and Aerlyn Weissman," Rites (September/October 1991).

5 “"The Wells of Loneliness': 'Secret Novel' Banned in England," Hush, 11 October 1928, p. 5. "Oh! Ye Daughters of Lesbia," Hush, 11 April 1929, p. 8.

${ }^{6}$ The issues of Hush discussed in this report are available at the Archives of Ontario. Given the rarity and increasing research importance of tabloids, there is a pressing need for a nation-wide inventory of and guide to the tabloid press in Canada, particularly for the pre-World War Two period. As it stands now, broken runs of various tabloids are scattered in different libraries and archives where they often remain uncatalogued and unorganized.

${ }^{7}$ S. H. Hooke, “A Biological Sin," Canadian Forum, April 1929, pp. 243-44. See Steven Maynard, "Radclyffe Hall in Canada," Centre/Fold: Newsletter of the Toronto Centre for Lesbian and Gay Studies 6 (1994), 9.

${ }^{8}$ Laura Doan, Fashioning Sapphism: The Origins of a Modern English Lesbian Culture (New York: Columbia University Press, 2001), xii, xvii, and xxiii. See also Palatable Poison: Critical Perspectives on 'The Well of Loneliness,' ed. Laura Doan and Jay Prosser (New York: Columbia University Press, 2002).

${ }^{9}$ Susan E. Houston, "'A little steam, a little sizzle and a little sleaze': English-Language Tabloids in the Interwar Period," Papers of the Bibliographical Society of Canada 40 (Spring 2002): 41, 45, 59. The brief sketch of early tabloid history offered in this paragraph draws heavily on Houston's study.

10 “"The Wells of Loneliness': 'Secret Novel' Banned in England," Hush, 11 October 1928 , p. 5.

${ }^{11}$ Doan, Fashioning Sapphism, 25. Hooke, "A Biological Sin," pp. 243-44.

12 "The Wells of Loneliness': 'Secret Novel' Banned in England," Hush, 11 October 1928, p. 5. Doan, Fashioning Sapphism, 26.

13 "A Man-Women Wrecks Her Home," Hush, 9 May 1929, p. 9.

${ }^{14}$ Doan, Fashioning Sapphism, 25. "The Wells of Loneliness: 'Secret Novel' Banned," Hush, 11 October 1928, p. 5; "Ethics of Lesbianism Banned: Copies of "The Wells of Loneliness' to be Destroyed," Hush, 18 December 1928, p. 10.

15 "Ethics of Lesbianism Banned," Hush, 18 December 1928, p. 10.

16 "Hell Witches in Toronto," Hush, 18 April 1929, p. 8; "Oh! Ye Daughters of Lesbia," Hush, 11 April 1929, p. 8; "Another Woman 'Weds' a Woman," Hush, 24 October 1929, p. 15.

17 "Ethics of Lesbianism Banned," Hush, 18 December 1928, p. 10; "A Man-Woman Wrecks Her Home," Hush, 9 May 1929, p. 9; Esther Newton, "The Mythic Mannish Lesbian: Radelyffe Hall and the New Woman," in Hidden From History: Reclaiming the Gay and Lesbian Past, ed. Martin Duberman, Martha Vicinus, and George Chauncey (New York: Meridian, 1989), 281-93.

18 "Hell Witches in Toronto: How the Infamous Mrs. X Thrashed Eight Society Women," Hush, 18 April 1929, p. 8. 
19 "Shameless Women's Terrible Toll," Hush, 16 May 1929, p. 9. Vicinus, "They Wonder to Which Sex I Belong," 438.

20 "Another Woman 'Weds' a Woman," Hush, 24 October 1929, p. 15; "Hamilton Masculine Woman," Hush, 2 March 1940, p. 2. On narratives of cross-dressing female husbands, see Vicinus, "'They Wonder to Which Sex I Belong."”

${ }^{21}$ Houston, "A little steam, a little sizzle and a little sleaze," 51.

${ }^{22}$ See, for example, Madge Pon, "Like a Chinese Puzzle: The Construction of Chinese Masculinity in Jack Canuck," in Gender and History in Canada, ed. Joy Parr and Mark Rosenfeld (Toronto: Copp Clark, 1996), 88-100.

23 "Hell Witches in Toronto," Hush, 18 April 1929, p. 8; "Hamilton Masculine Woman," Hush, 2 March 1940, 2; "Ethics of Lesbianism Banned," Hush, 18 December 1928, p. 10; "A Man-Woman Wrecks Her Home, Hush, 9 May 1929, pp. 9-11.

24 "Oh! Ye Daughters of Lesbia," Hush, 11 April 1929, 8; "Hell Witches in Toronto," Hush, 18 April 1929, p. 8; "Shameless Women's Terrible Toll," Hush, 16 May 1929, p. 9.

${ }^{25}$ Houston, "A little steam, a little sizzle and a little sleaze," 41. "Oh! Ye Daughters of Lesbia," Hush, 11 April 1929, p. 8; "Hell Witches in Toronto," Hush, 18 April 1929, p. 8.

26 "The Wells of Loneliness," Hush, 17 December 1928, p. 5; "Hell Witches in Toronto," Hush, 18 April 1929, p. 8; Hooke, "A Biological Sin," 244.

${ }^{27}$ Duder, "“That Repulsive Abnormal Creature I Heard of in That Book," 262-63.

${ }^{28}$ Lisa Duggan, Sapphic Slashers: Sex, Violence, and American Modernity (Durham, NC: Duke University Press, 2000).

${ }^{29}$ Duder, "Public Acts and Private Languages," 21.

30 "Hamilton Masculine Woman," Hush, 2 March 1940, p. 2.

31 "The Wells of Loneliness," Hush, 27 December 1928, p. 5; "Oh! Ye Daughters of Lesbia," Hush, 11 April 1929, p. 8. 